\title{
Ever Onward: The Frontier Myth and the Information Age
}

\author{
Jack Shuler
}

In 1995 Bill Gates, the software pioneer, entrepreneur, billionaire, and now philanthropist, offered a critique of a term made famous by former vice-president and champion of the Internet[1] Al Gore. In The Road Ahead, Gates argues that the term for the emerging communication network, the "information superhighway," is ill-conceived. He writes, "The phrase suggests landscape and geography, a distance between points... When you hear the phrase 'information superhighway, rather than seeing a road imagine a marketplace or exchange" (Gates, Myhrvold, and Rinearson 1995: 5-6). Both metaphors are apropos. The former describes a network crisscrossing a landscape, with on-ramps and off-ramps, exits and entrances, stores and outposts, commerce and society intertwined along the route. The latter suggests a location for trade in goods and ideas where the conversation is as important as the business at hand. Both metaphors describe places.

In an essay published the same year as The Road Ahead, media critic Laura Miller suggests that "The Net... occupies precisely no physical space (although the computers and phone lines that make it possible do). It is a completely bodyless, symbolic thing with no discernible boundaries or location" (Miller 2001: 215). This assertion appears alongside a critique of contemporary use of language that is part and parcel of the frontier myth-the belief that the presence of open space coupled with a pioneering and entrepreneurial spirit best explains the growth of the United States. Miller is particularly critical of those who use the notion of the frontier in connection with the Internet. She claims that the Internet is a created space without limits while the "frontier" was contained within specific geographic boundaries, national borders, and, eventually, barbed-wire fences. Yet the Internet does have boundaries, limits, despite the fact that it is created space. Miller acknowledges this fact herself when discussing the necessity of material ownership_phone lines, digital cables, computers_for entering cyberspace.[2] By claiming that the Internet is without boundaries, she too takes part in the discourse of the frontier myth by conjuring up images of unbounded freedom.

Indeed, the Internet lacks the kinds of physical borders one imagines existed on the frontier, but it is very much a part of the physical and material world and is thus subject to the limits and regulations of that world. If we only conceive of the Internet as existing in some virtual reality or cyberspace, we will lose sight of the fact that it is inextricably linked to material conceptions of space, place, and, consequently, ownership of that space. This space includes not only the cables that link computers — the information superhighway-but the computers themselves, email and web addresses, chat rooms, and domain names. Increasingly governments, corporations, and civil society groups are working to limit the "freedom" of the Internet by creating boundaries, borders, and fences around and within these spaces. Users are asked to stake a claim, to seize upon some part of the space or to not trespass upon the space of others. Yet as this occurs - as court battles rage over copyrights and domain names, over the CIA's "Carnivore" program and the existence of the digital divide- the frontier myth and its accompanying discourse of freedom persists.

Recently the oft-described anarcho-libertarian ideology of "open source technology" has been co-opted by IBM in an ad campaign focusing on the freedom and limitless possibilities of the Linux operating system-one of the most the most successful open source projects. Linux was developed from an operating system called UNIX in 1991 by a Helsinki student named Linus Torvalds. Rather than keeping the source-code for his new software a secret, he published it on the burgeoning Internet allowing other programmers to examine it and improve it. Thus 
the term "open source." Linux has gained the reputation, and rightfully so, for being a solid operating system that rarely crashes, unlike Microsoft's ubiquitous Windows which has a secret source-code.

During the 2004 Super Bowl, IBM launched its "Open" advertisement campaign—to promote the use of Linux with a series of commercials starring a blonde-haired boy in white t-shirt and blue jeans. This "golden child," we learn in later advertisements, is named Linux-just like the operating system. In one ad an announcer claims that nay-sayers believe "a closed world is a better world...The barriers are for your protection" (www.ibm.com/ open, Sept. 29, 2004). The ad closes with two brief statements that flash on the screen: "Linux is ready. The future is open." In other ads the child sits thoughtfully in a chair in notable locales all over the world accompanied by an announcement that "The child went east, then west, then north, then south." IBM is selling the myth that with open source technology comes freedom, that with public access to programming source-code-the foundation of the digital world and of cyberspace-the world will become more unified and free. What is actually happening is the beginning of the end of the "open range" in cyberspace. For years programmers have been sharing code, i.e. property, in cyberspace, but now the technology industry has taken an interest and has begun to settle, claim, and purchase this code. In May Torvalds himself officially announced that those contributing to Linux must "sign their work and vouch for its origin" (Lohr 2004: 11). This policy was enacted, according to Torvalds, to protect against lawsuits amongst programmers and corporations over the origins of source-codes. Such policies are being enacted at the same time corporations like IBM are taking an interest in open source projects. Thus a cynical view of the situation is that IBM seeks to corner the market, to end Microsoft's control over operating system software, and perhaps create their own in the process. IBM is surveying a territory in hopes of staking a claim. Now that they have begun to stake that claim, with the help of copyright laws, the government will back them up. This is the story of the frontier in the United States in a nutshell. As soon as freedom is announced, as soon as a free-space is declared, it becomes settled, regulated, and purchased.

By describing the Internet as a frontier, pundits, entrepreneurs, and politicians are taking part in a discourse that has existed in this country for many years. The contemporary version of the frontier myth presents the Internet as a freewheeling space crafted by wily pioneers and ingenious scientists which is being populated by those who wish to participate in the space's inherent freedom. The superhighway metaphor adds to this vision by promoting images of construction: breaking ground, dynamiting through nature, and conquering space. Pioneering computer scientists did lead the way in developing the Internet, but they did so, for the most part, with the support of lawmakers and government officials. The U.S. government continues to watch over the Internet as there are significant reasonscommercial, military and cultural—for monitoring the "settlement" of this frontier. Some who monitor this frontier view it as a dangerous place that needs to be regulated in order to prevent the corruption of the American public-in particular, children. Note the many attempts by governments and activists to control and limit the content and use of the Internet.[3]

Several American writers in the 18th and 19th century, including Charles Brockden Brown, James Fennimore Cooper, J. Hector St. John de Crevecouer, and Thomas Jefferson, portray the frontier as both a place of limitless possibilities and a place to be feared. It was also a place to be conquered and controlled. This is most evident in the close attention Jefferson paid to legal precedence. His Notes on the State of Virginia foreshadows not only the possibilities of the frontier but the reality that the frontier as free space would be short-lived. Accordingly, by the end of the 19th Century the Superintendent of the Census announced the closing of the frontier in the United States. A little over one hundred years later pundits were announcing the closing of the technological frontier--the Internet. This more recent closing hints at a conscious desire to limit certain freedoms, to limit possibilities in a very real and material way. Thus an ambiguous view of the Internet as frontier emerges. On one hand, there are those who claim that it will provide limitless possibilities; on the other hand, there are those who believe it should be controlled. And sometimes such opinions are voiced by the same people.

\section{What Is the Frontier?}

Frederick Jackson Turner's 1893 paper “The Significance of the Frontier in American History,” is cited here as a default foundational text of the frontier myth or what some call the "Turner Doctrine" or "Turner Thesis." His essay opens with the Superintendent of the Census's pronouncement in 1890 that the West, the frontier, had been settled (Turner 1962: 1). This was a turning point in American history because, according to Turner, the westward expansion 
was the catalyst for the country's creation: "The existence of an area of free land, its continuous recession, and the advance of American settlement westward, explain American development." American life, he writes, is "continually beginning over again"; it is "fluid" (Turner 1962: 2). This fluidity and a need to work with and for the advancement of the frontier have even shaped institutions. Turner points out that, "legislation with regard to land, tariff, and internal improvements... was conditioned on frontier ideas and needs” (Turner 1962: 27). Most importantly, Turner believes that the frontier promoted democracy (Turner 1962: 30).

Indeed, the advance westward managed to shape the American psyche. According to Turner's scenario, each advance beyond the boundaries causes pioneers to step briefly into a world of savagery. The pioneers are transformed by this new environment, a free space apart from the rigors of civilization. However, Turner acknowledges, "civilization" and all its material advantages is not far behind as the frontier must, out of economic necessity, link up with cities, commerce, the Atlantic coast (Turner 1962: 6-7, 11). Trading posts act as the first advance of civilization and are followed shortly by army posts established to protect settlers from Natives. Settlement of the frontier, as described by Turner, is driven by the market.

Turner asserts that it is part of the nature of Americans to always advance rather than establish roots. So it was with the pioneers: "the demand for land and the love of wilderness freedom drew the frontier ever onward" (Turner 1962: 22). Turner believes that "movement" is "the dominant fact" of the United States and will likely continue to be so as "the American energy will continually demand a wider field for its exercise" (Turner 1962: 37). Americans are pulled by the existence of limitless possibility and will always need some outlet.

The "Turner Doctrine" defined Western history for decades until the latter part of the 20th century when a number of scholars, including Patricia Nelson Limerick, began to criticize the essentialist tendencies of this school of thought. Through her work Limerick seeks a more expansive history of the frontier that is not only about the spirit of the ever-conquering white male pioneer. She writes, "Turner's frontier rested on a single point of view; it required that the observer stand in the East and look to the West. Now like many scholars in other fields, Western historians have had to learn to live with relativism" (Limerick 1987: 25-6). The American history Limerick presents is one of competing narratives of race, ethnicity, and gender that cannot be summarized in one tight thesis. Despite the efforts of Limerick and other historians, popular culture continues to be enthralled by the Turnerian history of the frontier and its accompanying myths of cowboys, coyotes, and buffalo. Henry Nash Smith notes that the "Turner doctrine" is significant, despite its flaws, because, "It concerns the image of themselves which many-perhaps most-Americans of the present day cherish, an image that defines what Americans think of their past, and therefore what they propose to make of themselves in the future" (Smith 1950: 4). When the Smithsonian presented a more realistic portrait of the American frontier in a 1991 exhibit entitled "The West as America," there was some public outcry, and the museum's guest book received more than a few negative entries about the exhibit. Shortly thereafter, “Two Western senators...threaten[ed] to cut the Smithsonian's budget for this lapse in patriotism" (Limerick 1996: 15). Senatorial objections aside, the frontier was and is a contested space, and our relationship to this contested space is fraught with contradictions. Even amidst the tumultuous conception of the United States, Thomas Jefferson wrestled with these contradictions. On the one hand, he and other American writers saw the frontier as a place that could provide limitless freedom; on the other it is a place that must be controlled and regulated.

\section{| Property $=$ Freedom}

In Virgin Land Henry Nash Smith refers to Thomas Jefferson as "the intellectual father of the American advance to the Pacific" and pays close attention to the expedition of Meriwether Lewis and William Clark across the Rockies and into the Northwest (Smith 1950: 15). Jefferson wished to find a trade route up the Missouri River that would best the routes being used by the British. More American fur traders in this part of the frontier would mean a stronger hold on the area. Profits would lead to progress and the nation would be closer to controlling the frontier. On a practical level Lewis and Clark's mission was about economics and politics. But for Smith,

the importance of the Lewis and Clark expedition lay on the level of imagination: it was drama, it was the enactment of a myth that embodied the future...and established the image of a highway across the continent so firmly in the minds of Americans that repeated failures could not shake it. (Smith 1950: 17)

Jefferson's connections to these "repeated failures" and his relationship to westward expansion will, in many respects, frame my discussion of the frontier myth. In his Notes on the State of Virginia one discovers his interest in 
exploring the frontier, as well as his desire to control that exploration and future settlement schemes. In the exactness of Jefferson's descriptions is an underlying desire to explain and learn all he can about his state of Virginia-the Enlightenment scholar in him comes to the foreground. Jefferson's support of the expedition of Lewis and Clark is an extension of that desire to know and understand the nature of U.S. territory. If one knows the frontier, one can control the settlement of the frontier, and help keep the country united. Therefore we must not read Jefferson's meticulous lists of vegetables in Query VI as an exercise in botany but as a useful catalog for future investors and settlers.

This "cataloging" began when a number of queries were submitted to Jefferson by Francois Marbois in 1780, a trying time for the infant country, to say the least. Jefferson's twenty-three responses appear to be an attempt to show the French that this American "experiment" has a future. With exquisite precision he provides a detailed picture of the state of Virginia as he saw it as well as his own vision for the political future of that state and of the United States of America. Jefferson's vision for the U.S. does not include industrial cities as found in Europe (Jefferson 1999: 171). His would be a nation of farmers because, "Those who labour in the earth are the chosen people of God, if ever he had a chosen people, whose breasts he has made his peculiar deposit for substantial and genuine virtue" Jefferson 1999:170). We must leave manufacturing to Europe because it leads only to the "mobs of great cities" (Jefferson 1999: 171). He notes, "It is the manners and spirit of a people which preserve a republic in vigour. A degeneracy in these is a canker which soon eats to the heart of its laws and constitution." For Jefferson, farms are a means to preserve what Leo Marx calls "rural virtue" and are not necessarily dynamic financial catalysts for the new nation (Jefferson 1999: 126). But rapid economic growth is less important for Jefferson than social and political stability. His rural ideal would preserve the political structure, initiating "a virtual stasis that is a counterpart of the desired psychic balance or peace" (Levy 2005: 127). The development of this rural utopia and of long-term economic prosperity depends on the existence of the frontier. So, as Jefferson notes in Query XIX, America can avoid Industrial Europe's perils because of "an immensity of land courting the industry of the husbandman" (Jefferson 1999: 170).

Before Jefferson's vision could come to pass, the U.S. had to establish itself within the global community. One might view as a good will gesture to the world, or France, his desire "to throw open the doors of commerce, and to knock off all its shackles, giving perfect freedom to all persons for the vent of whatever they may chuse to bring into our ports, and asking the same in theirs" (Jefferson 1999: 180). Jefferson also "establishes" the US by including a lengthy catalog of documents that ground the U.S. in text, and therefore law. Query XXIII proves ownership of property by listing a variety of deeds and treaties that outline how the United States came to be. For example, the sixth text listed, dated February 6, 1583, is, "The letters-patent granted by her Majestie to Sir Humphrey Gilbert, knight, for the inhabiting and planning of our people in America" (Jefferson 1999: 185). Another from 1664 is a "conveiance of the Delaware counties to William Penn" (Jefferson 1999: 193). These texts provide a narrative of ownership, an archive that exhibits the American commitment to private property that has, in important ways, fueled the frontier myth. And most important for Jefferson, his ideal country rests on notions of ownership-the yeoman must own the farm he cultivates. Thus he includes in Notes on the State of Virginia an example of how land can come into possession - a potential model for acquiring and declaring ownership of the frontier.

Jefferson's apparent desire to control frontier settlement was rooted in a commitment to private property. Such a commitment has its greatest support in the U.S. Constitution which provides the ultimate protections of private property. The document opens with a preamble which includes the phrase, "secure the blessings of Liberty" and can be read as an endorsement of Lockean notions of the right to private property. The "5th Amendment" of the Constitution acknowledges that in the U.S. no one, "shall be compelled in any criminal case to be a witness against himself, nor be deprived of life, liberty, or property, without due process of law; nor shall private property be taken for public use, without just compensation." This was later clarified and expanded in the "14th Amendment" with the claim that states cannot "deprive" citizens of the United States of America "of life, liberty, or property, without the due process of law."

The right to private property is viewed by many as a quintessential value of the U.S. James Fennimore Cooper asserted that,

If we would have civilization and the exertion indispensable to its success, we must have property; if we have property, we must have its rights; if we have the rights of property, we must take those consequences of the rights of property which are inseparable from the rights themselves. (Cooper 1953: 46)

Property is viewed as an American right. In Letters from an American Farmer, written around the same time that Jefferson wrote his Notes, J. Hector St. John de Crevecoeur ties the ownership of land to the limitless possibilities 
available to Americans, "a people of cultivators, scattered over an immense territory" (Cooper 1956: 36). In the U.S., he adds, "a man is free as he ought to be (Cooper 1956: 37). Crevecoeur believes America is a country of farmers of many nations, a place of promise for those who once lived in abject poverty in Europe: "Let him go to work, he will have opportunities enough to earn a comfortable support, and even the means of procuring some land" (Cooper 1956: 63). The emphasis is on owning property because with property-with ownership of and control of space_comes an apparent freedom for the individual. He writes, "The instant I enter my own land, the bright idea of property, of exclusive right, of independence exalt my mind. Precious soil... What should we American farmers be without distinct possession of that soil?" (Cooper 1953: 20).

In the 1840's the desire to own land was an important aspect of the popular belief in Manifest Destiny-the idea that it is the destiny of the U.S. to continue to grow and advance to the Pacific, laying claim to all territory along the way. Manifest Destiny is an expression of a much-shared belief in the necessity of property for prosperity and in the inherent exceptional nature of the American project. John L. O'Sullivan was one champion of this brand of American exceptionalism. In 1839 he wrote of the need to push onward to greatness and proclaimed, "The far-reaching, the boundless will be the era of American greatness. In its magnificent domain of space and time, the nation of many nations is destined to manifest to mankind the excellence of divine principles" (O'Sullivan, September 29, 2004). This project of "the great nation of futurity," willed by God and furthered by the existence of open land, will ultimately lead to the "universality of freedom and equality." This God-willed nation, like the utopia that Jefferson envisions, is dependent on the existence of the frontier.

More recently the discourse of the frontier myth haunts popular representations of the Internet. Critic Howard Rheingold is one of the most outspoken champions of the Internet as a frontier of freedom that can create bridges between cultures and foster a more utopian society. He employs this version of the frontier myth in the title of his 1993 book, The Virtual Community: Homesteading on the Electronic Frontier. He writes, "I have written this book to help inform a wider population about the potential importance of cyberspace to political liberties and the ways virtual communities are likely to change our experience of the real world, as individuals and communities" (Rheingold 2001: 275). As he writes of these online communities or "colonies of enthusiasts," he can hardly contain his enthusiasm for the Internet (Rheingold 2001: 276). When describing his interactions with Whole Earth 'Lectronic Link (WELL), a global virtual community, Rheingold exclaims,

Not only do I inhabit my virtual communities; to the degree that I carry around their conversations in my head and begin to mix it up with them in real life, my virtual communities also inhabit my life. I've been colonized; my sense of family at the most fundamental level has been virtualized. (Rheingold 2001: 280)

But Rheingold fears the intrusions of "big power and big money" into these virtual colonies/communities. We must, he says, "make sure this new sphere of vital human discourse remains open to citizens of the planet before the political and economic big boys seize it" (Rheingold 2001: 275).

In "A Declaration of the Independence of Cyberspace," written in 1996, Electronic Frontier Foundation founder, John Perry Barlow, like Thomas Jefferson before him, denounces those who infringe upon the rights of "online colonists" (Barlow, September 29, 2004). Like a messenger from the future, he writes, "Governments of the Industrial World, you weary giants of flesh and steel, I come from Cyberspace, the new home of Mind. On behalf of the future, I ask you of the past to leave us alone... You have no sovereignty where we gather." Perpetuating the idea that the Internet is not a part of the material world as typically defined, he adds, "Cyberspace does not lie within your borders. Do not think that you can build in it, as though it were a public construction project... Ours is a world that is both everywhere and nowhere, but it is not where bodies live." This is a new world where, "Your legal concepts of property, expression, identity, movement, and context do not apply to us. They are all based on matter, and there is no matter here." Barlow describes the on-going project of creating a utopian world without racial, economic, or cultural prejudice and without the horrors of war. He concludes by appearing to echo O'Sullivan and other supporters of Manifest Destiny: "We will spread ourselves across the Planet so that no one can arrest our thoughts. We will create a civilization of the Mind in Cyberspace. May it be more humane and fair than the world your governments have made before."

One could discredit Barlow's remarks as a relic of the 1960s. [4] That assertion might be credible if not for the work of Bill Gates who, in the introduction to The Road Ahead claims that

...we stand at the brink of another revolution. This one will involve unprecedentedly[5] inexpensive communication; all the computers will join together to communicate with us and for us. Interconnected globally, they will form a network, which is 
being called the information highway...I think we may be about to witness the realization of Adam Smith's ideal market, at last. (Gates, Myhrvold, and Rinearson 1995: 3-4)

This realization was reached by the hard work of many dedicated pioneers, himself included. He describes his own willingness to brook social norms by dropping out of Harvard to become an entrepreneur. Gates also includes in his self-mythologizing narrative the long hours he and Paul Allen dedicated to working on the development of Microsoft's groundbreaking contributions to the PC.

Gates connects the on-going rush to create the infrastructure to support the Internet to the Gold Rush (Gates 1995: 227). Governments, he claims, need to deregulate communications, rather than create more controls, in order to assist in this new "Gold Rush" (Gates 1995: 232). He insists this is of paramount importance because the development of the physical network that will carry the Internet has global economic implications: "Countries that move boldly and in concert with each other will enjoy economic rewards. Whole new markets will emerge, and a myriad new opportunities for employment will be created" (Gates 1995: 251). The creation of this network also has important cultural significance, similar to those posited by Rheingold and Barlow. Gates believes in the potential of the Internet to create a more utopian world. He claims that "[T] he information highway is going to break down boundaries and may promote a world culture" (Gates 1995: 263). People will be able to communicate with each other in ways they never could before. They will be free; their world will be open. He concludes, "I think it's a wonderful time to be alive. There have never been so many opportunities to do things that were impossible before" (Gates 1995: 276).

For one of the richest men in the world, it must be a wonderful time to be alive! One is reminded that in the late 19th century telegraph wires and railroads sliced through Native American lands. For them-and many others at the same time-there was little real access to these new communication technologies despite their presence. The communications gap is nothing new. But like many champions of the Internet, Gates pays lip service to some of the hidden problems that this space creates, most notably the widening gap between those who have access to computers and those who do not— the digital divide. Gates's own philanthropic efforts, particularly his efforts to bring PC's to public libraries, have centered on bridging this divide. And, in the process, he creates new customers. In this light, Microsoft's motto, "a computer on every desk and in every home" sounds like a slogan for a colonization effort (Gates 1995: 4). The digital divide dilemma brings up serious questions. Does the right to property include the right of everyone to have a presence in cyberspace? What happens if people are excluded from this frontier? Finally, should the colonizing of this space be regulated at all?

\section{Strange Voices in the Garden}

In the 2003 film, “Open Range,” [6] two gun-toting cowboys played by Robert Duvall and Kevin Costner are forced to reckon with a bullying rancher named Baxter, hell bent on keeping these cowboys-free-grazers as they are called - and their cattle off his property. In the culminating "high noon" showdown the townsfolk are forced to take sides with either the rich landowner or the idealistic cowboys whose time is coming to an end. Of course, they opt for the latter and come out victorious. In the aftermath, the townsfolk clean up and the cowboys ride into the sunset to sell their cattle as they announce that they'll return to the frontier settlement and open a saloon together. They recognize that the freedom of the open range has come to an end and it is time to settle, to claim a space for themselves.

But these two cowboys were never, technically, free. The frontier upon which they free-grazed their cattle was under the supervision of the U.S. government and before that it was the territory of Native Americans. The U.S. takeover was brutal as even Turner acknowledges: “The farmers met Indians with guns" (Turner 1962: 13). Like the open range of the frontier, communication on the Internet is also controlled. It is not free. It is controlled for reasons related to the need to monitor commerce and property as well as to the need to control cultural and political differences - to keep the outsider at bay. Jefferson notes that controlling the growth of the U.S., and ultimately how the frontier is settled, is imperative for maintaining the union:

It is for the happiness of those united in society to harmonize as much as possible in matters which they must of necessity transact together. Civil government being the sole object of forming societies, its administration must be conducted by common consent (Jefferson 1999: 91). 
Immigrants who come from monarchies will import ideologies which the U.S. wishes to cast off. Conversely, if these immigrants do indeed cast off these ideologies they may be "exchange[d] for an unbounded licentiousness... They will infuse into it their spirit, warp and bias its direction, and render it a heterogeneous, incoherent, distracted mass" (Jefferson 1999: 91). Jefferson repeats this sentiment in Query XIII: “The time to guard against corruption and tyranny, is before they shall have gotten hold of us. It is better to keep the wolf out of the fold, than to trust to drawing his teeth and talons after he shall have entered" (Jefferson 1999: 127). Jefferson proposes a slow increase in the population of the U.S. in order to make the government "more homogeneous, more peaceable, more durable" and ultimately, in his mind, the frontier and the nation would be safer (Jefferson 1999: 91). The country should not be in a rush to expand as there is plenty "of land to waste as we please" (Jefferson 1999: 92).

The potential instability and danger of frontier communities is a common theme in 19th century American literature. In the 1978 novel Wieland or, The Transformation: An American Tale, Charles Brockden Brown depicts an idyllic community on the edge of the wilderness that must contend with its own sort of "immigrant," an outsider named Carwin. This outsider speaks many languages and has no visible community. When he enters the story he is described by Clara Wieland as a "stranger" who appears in "the garb of a rustic" (Brown 2002: 66). But this "stranger" is actually an old acquaintance of Henry Pleyel, a member of the community. Pleyel met Carwin in Spain where Carwin had adopted the "habits of a Spaniard" even though he was, as we learn later, born in America (Brown 2002: 69). But Pleyel's "strange" friend Carwin has a talent that eventually causes great harm; he is a ventriloquist and can mimic the voices of others. It is believed by some that this "double-tongued deceiver" uses his talent to frighten the community and plunge Clara's brother Theodore into a moment of temporary insanity in which he murders his wife and children (Brown 2002: 233). He does so because he believes that he has received the word of God. Brown writes that, "This scene of havock was produced by an illusion of the senses" (Brown 2002: 223). Elizabeth Jane Wall Hinds notes that Theodore Wieland's "literal interpretation of the voice he hears is, unfortunately for him, in turn interpreted as madness: the court decides that his report of supernatural agency brands him as lunatic" (Brown 2002: 116).

One interpretation of Wieland is that the voice of the outsider who enters into this utopian rural community instigates madness. From another vantage point, Wieland's madness is the result of internal lapses. Brown courts such ambiguity for it raises potentially difficult questions. Keeping the wolf at bay is feasible-the frontier can be patrolled and immigration regulated-but the internal life of the subject cannot, especially when he or she is so far from "civilization." Brown seems to wonder aloud about the potential consequences of democracy; the lonely wilderness frontier becomes a place of danger and potentially disastrous consequences for the new nation. In Nathaniel Hawthorne's "Young Goodman Brown" the wilderness is also a place to be feared with sounds and voices that cannot be trusted: "The whole forest was peopled with frightful sounds; the creaking of the trees, the howling of wild beasts, and the yell of Indians" (Hawthorne 1985: 1041). The existence of such voices should, as Brown puts it, cause us to, "Hold!" We must be aware of the potential dangers to civilization that exist on the frontier and protect ourselves, all the while being vigilant of the dangers that lurk within.

In The American Democrat Cooper expresses concern over the multiplicity of voices in the new nation. Involved in numerous libel actions throughout his lifetime, his particular concern is with the abundance of periodicals. Cooper worries that too many voices - communication that is too free-will send the U.S. into a state of disarray and subvert its unity. He writes, "The admixture of truth and falsehood in the intelligence circulated by the press is one of the chief causes of its evils" (Cooper 1956: 130). There are, according to Cooper, too many opinions expressed by too many people. What has been created is a "government of opinion... which blindly yields its interests to the designs of those who would rule through the instrumentality of newspapers" (Cooper 1836: 131). He concludes, "As the press of this country now exists, it would seem to be expressly devised by the great agent of mischief, to depress and destroy all that is good, and to elevate all that is evil in the nation" (Cooper 1956: 132).

Because the Internet fosters the blending of cultures and, beyond that, easy access to information, many have become concerned. Will it allow dangerous voices to intrude into our culture and influence American politics and cultural attitudes? Will it allow for the theft of private property? Should it be regulated? One could argue that the Internet has always been regulated and controlled. The first computer network, the Advanced Research Projects Agency Network, or ARPAnet, was created in 1969 to allow for better communication amongst U.S. Department of Defense offices. This network was based on a Rand Corporation model for de-centralized communication in the event of a nuclear war. Thus, the territory was explored and settled years before Barlow's Electronic Frontier Foundation cried, "Foul!" and years before Carwin-like outsiders such as al Quaeda and child pornographers began 
their own explorations of the Internet frontier.

And so the view of this new frontier as a utopian space where democratic public discourse reigns is false. It is hardly such a place. Michael Totty of The Wall Street Journal writes, "If the early cyberspace was a separate frontier, outside the reach of governments and laws, it's now beginning to look more like a later version of the Old West - the one where settlers, marshals, and lawyers come in and impose law and order" (Totty 2003). He notes the recent entertainment copyright scandals and government efforts to end online gambling and control content. When a frontier emerges it is domesticated, made safe for commerce and "polite" society. According to Totty, "Courts and governments from New York to Washington to Beijing already are treating cyberspace like any other place within their jurisdictions. During last year's legislative session [2002], more than 400 bills seek to govern some aspect of the Net were introduced in Congress..." Even more intrusive than legislation are government-owned computer programs like the Central Intelligence Agency's "Carnivore" which can tap into a user's email account via Internet Service Providers' computers. The FBI has its own program called Cyber-Knight which serves a similar function. These programs have not gone unnoticed by advocates of free speech.

Media critics argue that many of the structures that limit freedom of discourse in the land of brick and mortar do the same in cyberspace. Lawrence Lessig believes that greater governmental and commercial control of the Internet will limit the freedom of users and cyberspace will be drained of its potential. He writes, "always and everywhere, free resources have been crucial to innovation and creativity... in the digital age, the central question becomes not whether government or the market should control a resource, but whether a resource should be controlled at all" (Lessig 2001: 14). He continues, "Just as we are beginning to see the power that free resources produce, changes in the architecture of the Internet—both legal and technical—are sapping the Internet of this power" (Lessig 2001: 15). Lessig's focus is on governmental and legal limitations to the freedom of cyberspace, while Alexander Galloway focuses on the technical limitations on this freedom-limitations that prohibit the free use of space. Galloway argues that the Internet is perhaps the most controlled environment that has ever existed because of standardized programming protocols that assert a hierarchy over computer operations on the Internet - how computers communicate with each other. "Protocol is a type of controlling logic that operates outside institutional, governmental, and corporate power, although it has important ties to all three" (Galloway 2004: 244). One of the most important protocols, which gives users and Internet Service Providers (ISPs) access to domains names, combines the power of programming protocol and a semi-governmental organization called the Internet Corporation for Assigned Names and Numbers (ICANN) into a regulating body that exerts immense power over the Internet. Various and unique voices are entering the garden, but the space they have in this new frontier is coming under greater scrutiny and regulation.

\section{Homesteading a Controlled Space}

The Homestead Act of 1862 was essentially a way for the U.S. government to settle the interior of the continent by putting more than over 270 million acres of land into the public domain. In order to stake a claim on this land, all someone had to do was build a house and cultivate some part of it, remaining there for at least five years. This proposal, Henry Nash Smith notes, was not for speculators or squatters; it was for laborers who would work the soil, for those who could prove themselves (Smith 1950: 170). The Homestead Act was Jefferson's ideal realizedyeoman farmers establishing utopian agricultural-based communities on the plains. Thus the act was not only an attempt to populate the mid-section of the country; it was an attempt to establish order and unity. The Homestead Act was announced after decades of work to establish a more united country, both geographically and ideologically. This should come as no surprise given the debate over slavery at the same time. Smith quotes William H. Seward demanding the admission of California in 1850 on grounds that the West should, "...meet again and mingle with the declining civilization of the East on our own free soil, and a new and more perfect civilization will arise to bless the earth..." (Smith 1950: 166). Settling the frontier, for Seward, is wrapped up in a vision of a more perfect nation and, certainly, free markets.

The Homestead Act was, in some respects, a failure. Of the land offered, the best lands ended up in the hands of speculators and railroads. "Railways alone," writes Smith, “... sold more land at an average price of five dollars an acre than was conveyed under the Homestead Act” (Smith 1950: 190). Freedom was declared but curtailed because this pioneering project was one engineered by the U.S. government. The Homestead Act spoke to the limitless possibilities of the frontier but was, in actuality, a method to control space. 
On the Internet frontier, settlers stake claims by giving themselves an address, a domain name. The word "domain" has its roots in the word "demesne," meaning possession or ownership. Therefore, "domain name" implies a name for something that is possessed or owned like a space or property. The names for Internet properties are controlled by a protocol called the Domain Name System (DNS). DNS is, in essence, a database connecting network addresses — which appear as a series of numbers - to network names - which appear as "www-dot's." Alexander Galloway explains that,

in order to visit 'www.rhizome.org' on the Internet one's computer must first translate the name 'www.rhizome.org,' itself geographically vague, into a specific address on the physical network. These specific addresses are written as a series of four numbers like so: 206.252.131.211. (Galloway 2004: 9)

They are also referred to as Internet Protocol or IP addresses. ICANN is responsible for this hierarchical DNS and for accrediting privately run domain name registrars. As part of its duties, ICANN also controls the kinds of suffixes (dot-org, dot-com, dot-edu, etc.) that can exist. The organization claims that its "role is very limited, and it is not responsible for many issues associated with the Internet, such as financial transactions, Internet content control, spam (unsolicited commercial email), Internet gambling, or data protection and privacy" (ICANN). One might dispute ICANN's assertion that its role is "limited." It is responsible for the DNS, a system that allocates the right to distribute "property" on the Internet. This organization controls the territory of the Internet, distributes property, and, with U.S. backing, lays claim to the frontier.

ICANN's mission statement claims its purpose is "to operate as an open, transparent, a consensus-based body that is broadly representative of the diverse stakeholder communities of the global Internet" (www.icann. org, September 29, 2004). This non-profit has come under increased opposition by media activists around the world who suggest that ICANN is anything but "transparent." Suspicion exists because ICANN was created at the behest of the U.S. Department of Commerce. The process of making ICANN a self-sustaining entity is underway, but many argue that its claims of diversity and internationalization are unfounded and that an Internet regulating body, if one exists at all, should be associated with the United Nations, not the United States.[7] Calls for a UN led organization were heard at last year's World Summit on the Information Society in Geneva but were met by much resistance from policymakers in Washington.

Why all the fuss? The naming of space on the Internet is actually quite significant given the number of people who are online. Domain names serve as portals to websites that have important private and public functions. Websites serve as resumes, commercial hubs, and entertainment centers. More important, the information a website contains can be seen by anyone who has access to the Internet. In 2002, the Christian fundamentalist preacher Jerry Falwell sued Gary Cohn for creating a satirical website that used the domain names www. jerryfallwell.com and www.jerryfalwell.com. Charges of trademark violations and libel, or, as one brief put it, "domain name hijacking," were filed in U.S. District Court in Virginia. These charges were ultimately dismissed on grounds that the court lacked jurisdiction over the case. In 2003, a new complaint was filed with a dispute resolution panel against Network Solutions, Inc., an ICANN accredited domain name registrar. Falwell's complaint was that the address www.fallwell.com[8] was registered—in "bad faith" and "out of anger" toward Falwell—with Network Solutions and was being used to re-direct potential visitors to his website. The panel ruled in Fallwell's favor and charged Network Solutions of "typosquatting" and ordered that the domain name be "transferred" over to Falwell (www.arbforum.com, September 29, 2004). The site still exists, but it is likely that Falwell will file charges in Federal court in the near future.

Many programmers argue that the way to keep the Internet free and "open" is to place programming sourcecode in the public domain. In this way, large corporations will not be able to control the ground upon which the Internet develops. In his essay, “The Cathedral and the Bazaar," Eric S. Raymond promotes the open source ideology discussed earlier. He believes that open source is the answer to all the bugs, or problems, that arise with most software. Raymond says this is because of the governing principles of open-source, what he calls, "Linus's Law" (named after Linus Torvalds)_"Given enough eyeballs, all bugs are shallow" (Raymond 1999: 30). In other words, if people collaborate to create software it will have fewer mistakes. The source-code of software must be kept public so that users can improve it. The downside of this is that it could create some sticky copyright battles.

Raymond asserts that the current structure of the Internet is based upon the highly regulated structure of a cathedral as opposed to what he desires, which would look more like a bazaar. The cathedral model is hierarchical and is fostered by large corporations and governments who seek to centralize service and content and even to 
protect the public from unwanted and sometimes dangerous "outsiders." Most of us welcome certain intrusions from a protective authority, of course, but the question is where should the line be drawn? Witness the ongoing debates around copyright (Napster, Gnutella), the ability of the U.S. government to force ISPs not to host certain sites, and the creation of media conglomerates that drown out the voices of smaller interests. Then again, if this free-space, this frontier, has since its inception been regulated by the government, any public outcry from "the homesteaders" is a waste of time. The Internet frontier never actually existed.

But did the frontier ever exist except as ideology? As soon as Europeans landed on the shores of the Americas, they began to describe what they saw - and kill those with a competing discourse. It is fitting to note how often European settlers gave names to those geographic features they encountered as they progressed across the continent, disregarding the names given them by Native Americans. This naming was also included in numerous treaties, surveys, and legal titles-technologies of ownership and settlement necessary for laying claim to the frontier. Richard Slotkin writes,

It is by now a commonplace that our adherence to the 'myth of the frontier'-the conception of America as a wide-open land of unlimited opportunity for the strong, ambitious, self-reliant individual to thrust his way to the top-has blinded us to the consequences of the industrial and urban revolutions and to the need for social reform and a new concept of individual and communal welfare (Slotkin 1996: 5).

Ultimately most visions of the frontier could not compete with industrial and governmental control. Part of the myth of the frontier is the vision of freedom, even when that vision is inherently rooted in a falsehood. It was never free. An Internet or communications frontier will never exist, and perhaps never has, because the Internet is rooted in conceptions of space and ownership of space that are guided by legal documents-including the U.S. Constitution - which give Americans the right to own space and the U.S. government permission to protect that space. Major social transformation would have to occur and a more communal understanding of property come into being, if we are to ever have a true frontier. Note what happened when outer space was announced as the "final frontier": NASA astronauts landed on the moon and planted a flag.

The American myth of the frontier is tied to a drive to create, to go forth, to become, to make and do. This drive is fueled by a desire for something new and an opposition to constraint. Reaching the new lands of the frontier, then, is about entering the land of the free. When Huck Finn is faced with the prospect of being constrained, of being "sivilized" by Aunt Salley, he declares, “...I reckon I got to light out for the territory ahead of the rest..." (Twain 1885: 279). Like Huck, many believe that if they explore the frontier they will be free and their lives will be better. The frontier, the "newest thing," will provide liberty, peace, and prosperity. This fantasy of freedom informs the discourse about the Internet. In reality the frontier exists to be regulated, controlled, and sold back to us for a profit.

\section{Endnotes}

1. Throughout this essay I will use the term Internet to signify not only the communications network that fosters the use of email but also the World Wide Web. It is a measure of simplification given that some of the critics I discuss, such as Howard Rheingold, did not use the term "World Wide Web" in their more important texts written in the early 1990 s.

2. The notion that the Internet is rooted in physical space is painfully apparent to urban teenagers waiting for hours to gain web access at community libraries, to developing nations desiring digital networks, and to victims of cyber-crimes.

3. See McLure, Helen. "The Wild, Wild Web: The Mythic American West and the Electronic Frontier."
Western Historical Quarterly, Winter (2000): 457 - 475.

4. Barlow was at one time a lyricist for the Grateful Dead.

5. Gates' word, or that of his editor, is not recognized as grammatically correct by the Microsoft Word program.

6. The film was shot in Alberta, Canada on Stoney Indian Reservation.

7. The frontier of cyberspace has also been "claimed" in other ways by the U.S., for example, through the establishment of English as the lingua franca of the web-this despite the widely held myth of the Internet as global village. 
8. On a recent attempt to enter this site, I was diverted to a satirical site www.fartwell.com. The ability of web activists, law enforcement agencies, and corporations to intercept individual attempts to visit a site raises some interesting questions.

\section{References}

Barlow, John Perry. "A Declaration of the Independence of Cyberspace." www.eff.org/ barlow/Declaration-Final.html Accessed September 29, 2004.

Brown, Charles Brockden. [1798] 2002. Wieland or, the Transformation: An American Tale. New York: The Modern Library.

Cooper, James Fenimore Cooper. [1838] 1956. The American Democrat. New York: Vintage Books.

Crevecoeur, J. Hector St. John de. [1782] 1957. Letters from an American Farmer. New York: EP Dutton and Company.

Galloway, Alexander R. 2004. Protocol. Cambridge, Massachusetts: The MIT Press.

Gates, Bill with Nathan Myhrvold and Peter Rinearson. 1995. The Road Ahead. New York: Viking.

Hawthorne, Nathaniel. [1835] 1985. "Young Goodman Brown." The Norton Anthology of American Literature, 2nd Edition. New York: WW Norton.

Hinds, Elizabeth Jane Wall. 1993. "Charles Brockden Brown and the Frontiers of Discourse" in Frontier Gothic: Terror and Wonder at the Frontier in American Literature, edited by David Mogen, Scott P. Sanders, and Joanne B. Karpinski. Rutherford: Farleigh Dickinson UP.

"ICANN Fact Sheet." www.icann.org. Accessed September 29, 2004.

Jefferson, Thomas. [1781] 1999. Notes on the State of Virginia. New York: Penguin.

Lessig, Lawrence. 2001. The Future of Ideas: the Fate of the Commons in a Connected World. New York: Vintage.

Limerick, Patricia Nelson. 1987. The Legacy of Conquest. New York: Norton.

----. 1996. “The Real West.” The Real West. Denver: Civic Center Cultural Complex.

Lohr, Steve. 2004. "R.I.P.: The Counterculture Aura of Linux." New York Times, May 25, 2004: C11.

McLure, Helen. 2000. "The Wild, Wild Web: The Mythic American West and the Electronic Frontier." Western Historical Quarterly, Winter: 457 - 475.
Marx, Leo. 1964. The Machine in the Garden. London: Oxford UP.

Miller, Laura. 2001. "Women and Children First: Gender and the Settling of the Electronic Frontier." Pp. 214 - 220 in Reading Digital Culture. edited by David Trend. Malden, Massachusetts: Blackwell.

National Arbitration Forum. Decision: The Reverend Dr. Jerry L. Falwell and The Liberty Alliance v. Lamparello International. Claim Number: FA0310000198936. http://www.arbforum. com/domains/decisions/198936.htm Accessed September 29, 2004 .

O'Sullivan, John L. [1839] “The Great Nation of Futurity.” The United States Democratic Review, Volume 6, Issue 23, (426430). www.mtholyoke.edu/acad/intrel/osulliva.htm Accessed September 29, 2004.

"Open." www.ibm.com/open Accessed September 29, 2004.

"Open Range." 2003. Buena Vista Studios.

Raymond, Eric S. 1999. The Cathedral and the Bazaar. Sebastopol, CA: O’Reilly.

Rheingold, Howard. 2001. "The Virtual Community." Pp. 272 - 280 in Reading Digital Culture, edited by David Trend. Malden, Massachusetts: Blackwell.

Slotkin, Richard. 1996. Regeneration through Violence. New York: Harper Collins.

Smith, Henry Nash. 1950. Virgin Land. Cambridge, Massachusetts: Harvard UP.

Totty, Michael. 2003.” Taming the Internet Frontier.” Wall Street Journal. April 14, 2003.

Turner, Frederick Jackson. [1893] 1962. The Frontier in American History. New York: Holt.

Twain, Mark. [1885] 1997. Adventures of Huckleberry Finn. New York: Signet.

Slotkin, Richard. 1996. Regeneration Through Violence. New York: Harper. 
